\title{
EQUILIBRIUM
}

Quarterly Journal of Economics and Economic Policy

2014 VOLUME 9 ISSUE 3, September

p-ISSN 1689-765X, e-ISSN 2353-3293

www.economic-policy.pl

Misztal P. (2014), The Hypothesis of Jobless Economic Growth in the Global Triad Countries, "Equilibrium. Quarterly Journal of Economics and Economic Policy", Volume 9, Issue 3, pp. 109-129, DOI: http://dx.doi.org/10.12775/EQUIL.2014.020

Piotr Misztal ${ }^{*}$

Jan Kochanowski University in Kielce, Poland

\section{The Hypothesis of Jobless Economic Growth in the Global Triad Countries}

JEL classification: $F 43, E 24, C 51$

Keywords: economic growth, employment, Okun 's law

\begin{abstract}
The aim of the study is to analyze the hypothesis of jobless economic growth in economic theory and in the Global Triad countries (U.S. , EU-15, Japan, China, India). In the article the research method based on the literature study in the field of macroeconomics and international finance were used, as well as econometric methods (Ordinary Least Squares). All the statistics used in the study had an annual frequency and covered the period from 1990 to 2012. These data came from the statistical database of the Business Membership and Research Association - The Conference Board Total Economy Database. On the basis of the study the phenomenon of jobless economic growth in China and India was revealed. However, in the case of the USA, the EU-15 and Japan the positive impact of economic growth on changes in employment was confirmed.
\end{abstract}

\section{Introduction}

The relationship between economic growth and employment is one of the most frequently discussed issues both in the economic literature as well as in national economic strategies. This is due to the fact that in most devel-

(C) Copyright Institute of Economic Research \& Polish Economic Society Branch in Toruń Date of submission: November 12, 2013; date of acceptance: May 16, 2014

*Contact: misztal@tkdami.net, Jan Kochanowski University in Kielce, Żeromskiego 5, 25-369 Kielce, Poland 
oped and developing countries a deficit in labor demand occurs and therefore there is a chronic unemployment problem. In addition, employment in these countries is not growing enough in the period of economic growth in order to help substantially to reduce unemployment. Hence, there is an urgent problem, which is the issue of the so-called jobless economic growth.

In accordance with the theoretical point of view, changes in employment depend both on economic growth, as well as the ability of the economy to absorb labor supply. Economic policy aimed at increasing the employment rate must therefore be addressed both in these areas, because the high rate of economic growth is not in itself a guarantee of employment growth.

The aim of this study is to analyze the hypothesis of jobless economic growth in economic theory and in the countries belonging to the so-called Global Triad (U.S., EU-15, Japan, China, India). In the article was used the analysis method based on literature studies in macroeconomics and international finance and econometric methods (Ordinary Least Squares). All statistics used in the paper had an annual frequency and cover the period from 1990 to 2012. These data were derived from the statistical basis of the Business Membership and Research Association - The Conference Board Total Economy Database.

\section{Economic growth, employment and unemployment in the light of theory}

In economic literature, the relationship between economic growth and unemployment is recognized as Okun's law (1962). According to Okun's law, the relationship between economic growth and decrease of unemployment (or increase of employment) is not one to one. Okun asserts that there is only a weak correlation between economic growth and lower unemployment. Namely, Okun's law says that the one-percent increase in the rate of economic growth above trend or potential growth leads to a decrease in unemployment by only 0.3 percent. Turning this relationship, it can be concluded that one-percent increase in unemployment will mean approximately more than three percent of the loss of economic growth. This relationship means that the GDP growth rate must be equal to the potential growth to keep unemployment stable. Therefore, in order to reduce unemployment (increase employment), GDP growth needs to be above the growth rate of potential output (Khemra et al., 2006). The greater elasticity of the unemployment rate to changes in GDP growth rate (typically in the 
range $0.3-0.5)$, the more likely the reduction of unemployment through economic growth. Okun's Law can be expressed using the following expression:

$$
\left(Y-Y^{\prime}\right)_{t}=-\beta \cdot\left(U-U^{\prime}\right)_{t}+\mu_{t}
$$

where:

$\mathrm{Y}$ - the current level of domestic production;

$\mathrm{Y}^{\prime}-$ the potential level of domestic production;

$\mathrm{U}$ - the current unemployment rate;

$\mathrm{U}$ '- the natural rate of unemployment;

$\beta$ - Okun's index;

$\mu$ - random component;

$\mathrm{t}-$ analyzed period.

It is clear that employment growth does not necessarily mean the same reduction in unemployment. This may result from an increase in labor supply in the country, resulting in the emergence of the market for new labor participation, and as a result of the inflow of foreign workers into the country. From a theoretical point of view, one can identify four different combinations of changes in the country's economic growth and employment.

Figure 1. Alternative scenarios of economic growth and employment

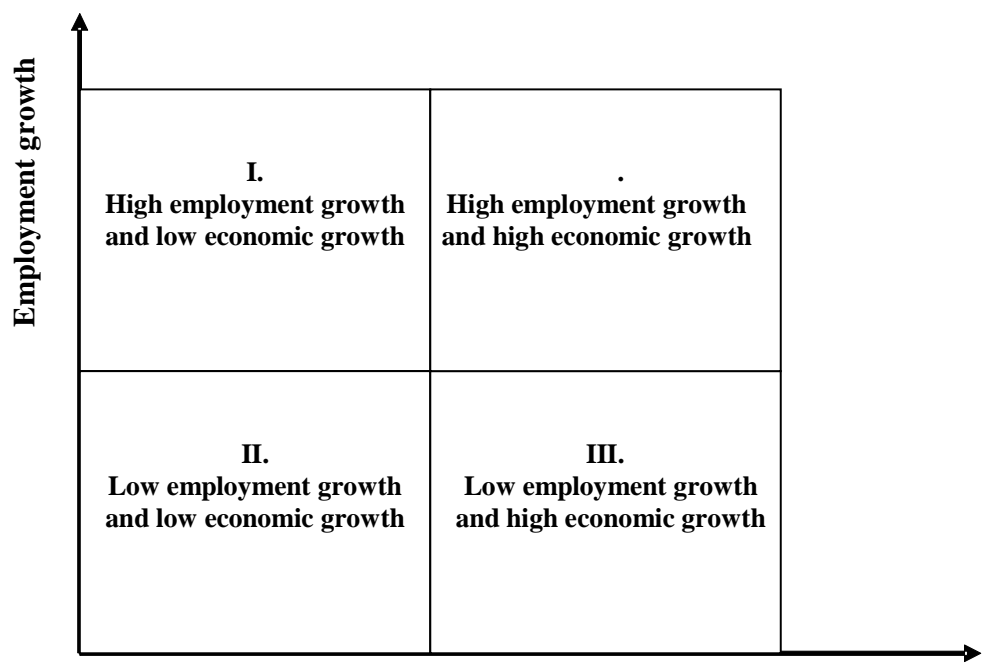

Edonomic growth

Source: Islam (2010). 


\section{Piotr Misztal}

The first (I) and second (II) variant means slow economic growth, while variants of the third (III) and fourth (IV) indicate the presence of high economic growth. What's more, in the third variant (III) a low employment growth takes place, which is the phenomenon of jobless economic growth.

Bhorat and Oosthuizen (2006) distinguish between three different forms of the phenomenon of jobless economic growth. The first form occurs when economic growth is accompanied by a zero or negative growth in employment. The second form of the analyzed phenomenon occurs when in the case of economic growth there is a time delay of employment in relation to the growth of the workforce, leading to a rise in unemployment. The third form of the studied phenomenon occurs when economic growth is accompanied by an increase in employment, but less than a "satisfactory" level.

If economic growth is at the same level as the dynamics of the labor supply, by definition, there is a jobless economic growth if labor productivity grows faster than economic growth. This situation may lead to changes in the relative prices of labor and capital and, consequently, to an increase in investment in more capital-intensive sectors of the economy (Altman, 2003).

From the country's economy point of view, the size of the domestic production is equal to the product of the employed labor force and productivity. This relationship can be expressed as the following equation:

$$
Y=L \cdot \frac{Y}{L}
$$

where:

$L$ - number of employees.

Taking into account the aforementioned changes, the above relationship can be written in the following form:

$$
\Delta Y=\Delta L+\Delta P
$$

where:

$\Delta$ - changes in given variable.

P - labor productivity, measured as: $\frac{L}{Y}$ 
The expression (3) indicates that economic growth is the sum of employment growth and labor productivity growth. It follows that the changes in the employment and labor productivity may be an important determinant of economic growth (Figure 2).

Figure 2. Economic growth factors

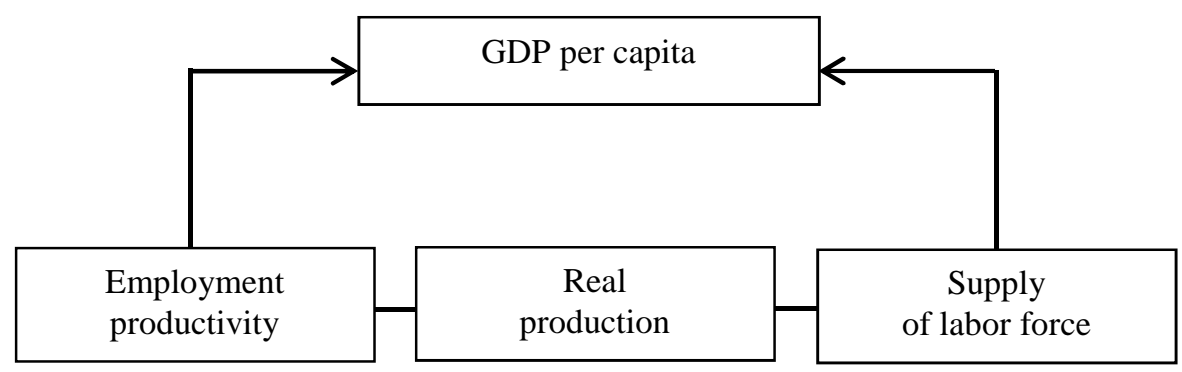

Source: own study based on the Ark et al. (2004).

Assuming a constant economic growth, any increase in the employment rate must correspond to equal decrease in labor productivity. Dividing expression (3) by the economic growth we get the following equation:

$$
\varepsilon=1-\frac{\Delta P}{\Delta Y}
$$

where:

$\varepsilon$ - the employment elasticity of economic growth, calculated as: $\varepsilon=\frac{\Delta L}{\Delta Y}$.

Employment elasticity index is calculated in order to determine the range of the impact of economic growth on changes in employment in given period. Using equation (4) we can indicate the different scenarios of economic growth and the relationship between employment elasticity and changes in employment and labor productivity. 
Table 1. Employment elasticity and changes in employment and labor productivity

\begin{tabular}{|c|c|c|}
\hline \multirow{2}{*}{$\begin{array}{c}\text { Employment } \\
\text { elasticity }\end{array}$} & \multicolumn{2}{|c|}{ Economic growth } \\
\cline { 2 - 3 } & Positive economic growth & Negative economic growth \\
\hline $\boldsymbol{\varepsilon}<\mathbf{0}$ & $\begin{array}{c}\text { The decrease in employment } \\
\text { Labor productivity growth }\end{array}$ & $\begin{array}{c}\text { Employment growth } \\
\text { The decrease in labor productivity }\end{array}$ \\
\hline $\mathbf{0} \leq \boldsymbol{\varepsilon} \leq \mathbf{1}$ & $\begin{array}{c}\text { Employment growth } \\
\text { Labor productivity growth }\end{array}$ & $\begin{array}{c}\text { The decrease in employment } \\
\text { The decrease in labor productivity }\end{array}$ \\
\hline $\boldsymbol{\varepsilon}>\mathbf{1}$ & $\begin{array}{c}\text { Employment growth } \\
\text { The decrease in labor productivity }\end{array}$ & $\begin{array}{c}\text { The decrease in employment } \\
\text { Labor productivity growth }\end{array}$ \\
\hline
\end{tabular}

Source: Kapsos (2005).

Employment elasticity index close to unity suggests that economic growth leads to an increase in employment, and the rate of employment elasticity close to zero indicates a low correlation between economic growth and employment. Thus, in this case the phenomenon of jobless economic growth occurs.

\section{Economic growth and employment in the light of the results of empirical investigations}

Empirical studies on the impact of economic growth on changes in employment in selected countries are increasingly based on previously mentioned Okun's law and examine the impact of cyclical changes in economic growth to cyclical changes in employment. For this purpose, time-series trend of the components is isolated to obtain a cyclical component. Most of this procedures is done by using the Hodrick -Prescott filter. As a result, the estimated employment elasticity indicators are based on a modified version of Okun's coefficient and they are calculated by the following formula :

$$
\left(L-L^{*}\right)_{t}=\alpha+\varphi \cdot\left(Y-Y^{*}\right)_{\mathrm{t}}+\mu_{t}
$$

where:

* - the trend component in the analyzed time series;

$\varphi$ - the employment elasticity of economic growth;

$\mu$ - random variable;

$\mathrm{t}$ - analyzed period. 
So far, in the economic literature there are many empirical studies on the relationship between employment and economic growth in selected countries and groups of countries. This work can be divided into two groups in terms of the relationship between employment and economic growth.

The first group of studies shows that growth and employment are not necessarily positively correlated and, therefore, jobless economic growth may occur. The second group of the analysis indicates the existence of a strong and positive relationship between economic growth and employment.

A study made by Swan and Vistrand (2006) indicates that the average employment elasticity of changes in GDP amounted to $0.7 \%$ in Sweden during 1980-2004 and did not change significantly over time.

Moosa (1997) argues that employment responds to changes in economic growth in greater degree in the United States and Canada than in Europe and Japan. In accordance with his opinion, these differences are the result of existing institutional differences that determine the elasticity of labor markets in different countries.

A similar claim is put forward by Lee (2000), who believes that economic growth affects employment growth, but the coefficients of the influence of economic growth on changes in employment vary significantly between individual countries as a consequence of the existing labor market rigidities.

What's more, Döpke says that the relationship between economic growth and employment is asymmetric, because the impact of economic growth on employment growth varies depending on the phase of the business cycle.

Moreover, Baker and Schmitt (1999) estimated Okun's coefficient for OECD countries, and stressed the importance of economic growth in partner countries as a determinant of national employment.

However, Pianta, Evangelista and Perani (1996) analyzed the relationship between economic growth and employment in 36 manufacturing sectors in G-7 member countries in the period 1980-1992 and concluded that the relationship between the two variables, although it was positive, it was not statistically significant.

The research carried out by Onaran (2008) in a group of eight Central and Eastern European countries confirmed the existence of a positive impact on employment growth in most of these countries, but the employment elasticity of economic growth was relatively low in the short run. In addition, in several countries a complete lack of impact of economic growth on employment was revealed (the Czech Republic, Bulgaria and Romania). 
Saget (2000) also studied the link between economic growth and employment in the 11 countries of Central and Eastern Europe and the Commonwealth of Independent States in the period 1989-1998. From the point of view of the employment elasticity of economic growth he divided the analyzed countries into three groups. In the first group, into which he included the countries such as Poland, Hungary and Slovenia, the increase in employment seemed closely linked to economic growth, which meant a relatively high employment elasticity in these countries. In the second group, into which he included the Baltic States, Slovakia and Russia, the employment elasticity of economic growth was much lower. However, in case if the third group of countries, into which Saget included Bulgaria, Romania and Ukraine, no statistically significant relationship between employment and economic growth was found.

Verdoorn and Kaldor estimated that accelerating growth of domestic production by $1 \%$ leads to both productivity and employment growth by a half percentage point. Therefore, the larger the increase in labor productivity due to the growth of national income, the greater the difficulty of limiting the rise in unemployment. Moreover, changes in labor productivity show stronger growth during the downward phase of the business cycle and weaker increase during the growth phase when the economic recovery in the most degree spreads on the labor market (Marczewski, 2006).

However, a study conducted by Walterskirchen (1999) suggests that the unemployment elasticity varies depending on the country concerned, in the range from 0.5 to 0.7 . This means that the share of additional jobs occupied by recorded in the registers of the unemployed are between $50 \%$ to $70 \%$. The rest of the additional jobs $(50 \%-30 \%)$ is occupied by an existing hidden reserves in the country's workforce, and the foreign workers.

\section{Research methodology and results of estimation}

In the economic literature, there are used a variety of different econometric models in order to estimate the impact of economic growth on changes in employment in selected countries. In order to analyze the problem of jobless economic growth in the Global Triad in the article was used the model presented in the following equation: 


$$
\Delta L_{t}=\alpha+\sigma \cdot \Delta Y_{\mathrm{t}}+\mu_{t}
$$

where:

$\omega$ - the employment elasticity of economic growth.

All time series used in model had an annual frequency and covered the period from 1990 to 2012. In addition, all variables were logarithmed, in order to receive a linear estimator of the parameters (Figure 3 ).

Figure 3. Changes in economic growth and employment in selected countries in the period 1990-2012
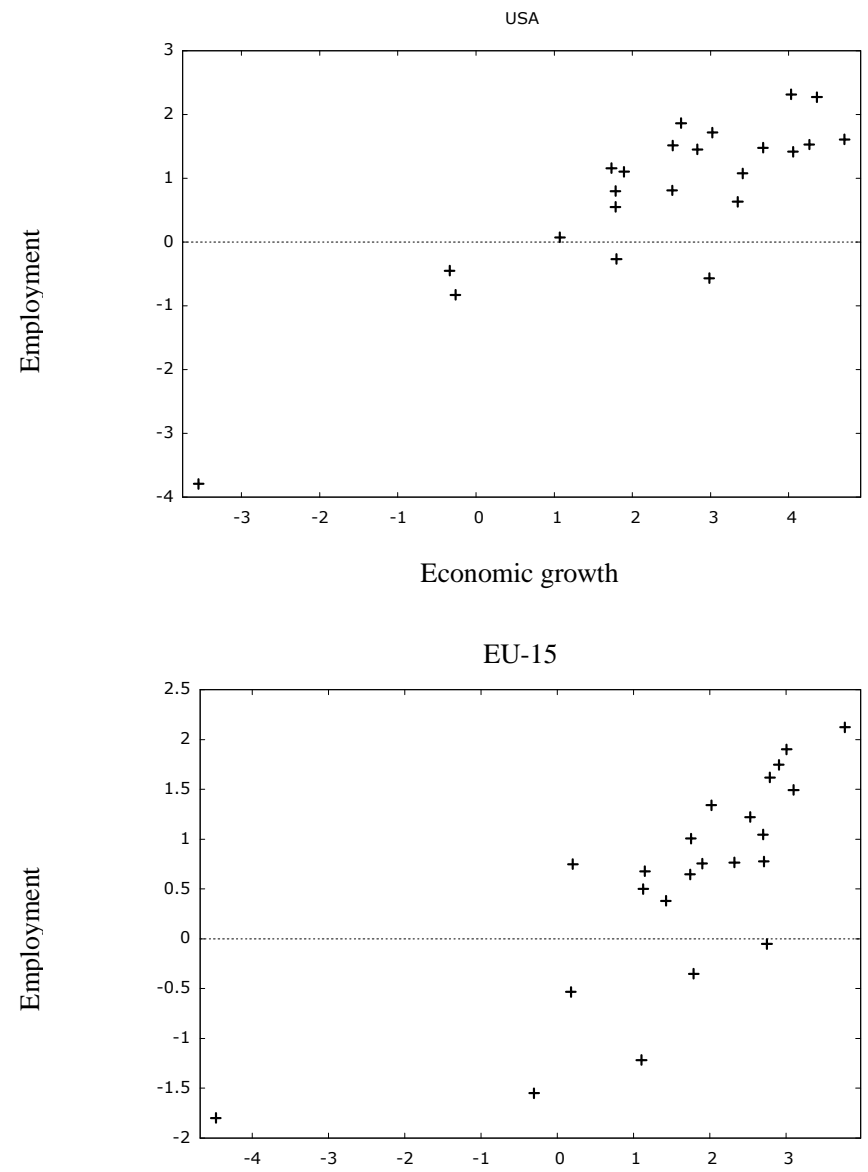
Figure 3 Continued

\section{Economic growth}

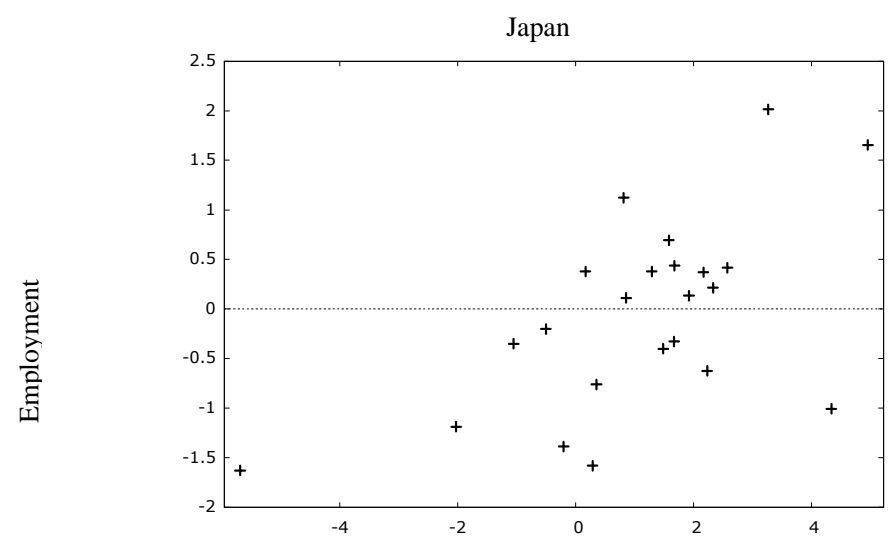

Economic growth

China

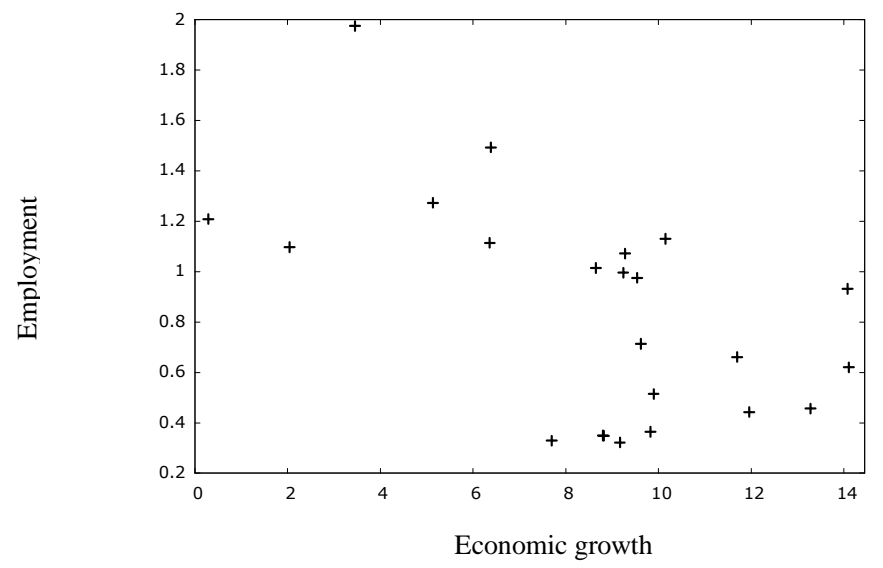


Figure 3 Coninued

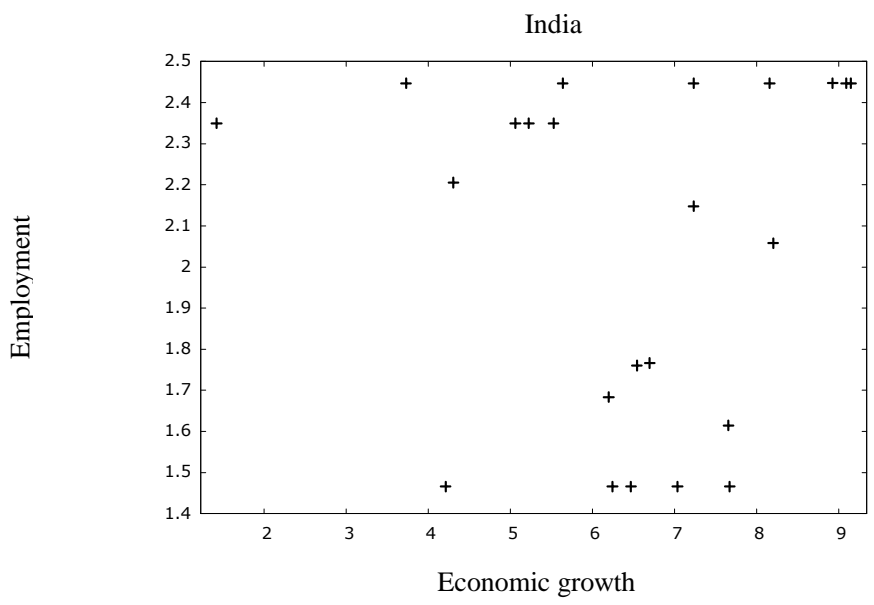

Source: own study based on The Conference Board Total Economy Database (2012).

According to Figure 3, in the case of three analyzed economies the equilibrium took place in a situation of relatively high economic growth and high employment growth, which means the rejection of the hypothesis of jobless economic growth. However, in the case of two countries (China and India) equilibrium occurred with a relatively high economic growth and low employment growth, indicating the presence of the hypothesis of jobless economic growth. This rule was confirmed by the calculated correlations between economic growth and employment growth in the analyzed countries in the period 1990-2012.

Table 2. The correlation coefficients between economic growth and employment growth in the analyzed countries in the period 1990-2012

\begin{tabular}{|l|c|c|c|c|c|}
\hline Countries & USA & EU-15 & Japan & China & India \\
\hline The correlation coefficient & 0.87 & 0.79 & 0.59 & -0.56 & -0.02 \\
\hline
\end{tabular}

Source: own calculations.

According to the data presented in Table 2, in the three surveyed economies (U.S., EU-15, Japan) the calculated correlation coefficients had a relatively high positive values, while in the case of China and India it were reported a negative correlation coefficients. Similar conclusions can 
be drawn after estimating equation (6) using the Ordinary Least Squares method.

Table 3. The estimation of equation (6) using OLS, observations used 1990-2012 $(\mathrm{N}=23)$, dependent variable: $\Delta L$

\begin{tabular}{|c|c|c|c|c|c|c|}
\hline & Coefficient & Stand. error & t-ratio & $p$-value & Significance & $\overline{\mathbf{R}^{2}}$ \\
\hline \multicolumn{7}{|c|}{ USA } \\
\hline const & -0.709122 & 0.224626 & -3.1569 & 0.00476 & $* * *$ & \multirow[t]{2}{*}{0.76} \\
\hline$\Delta Y$ & 0.62212 & 0.0753998 & 8.2509 & $<0.00001$ & $* * *$ & \\
\hline \multicolumn{7}{|c|}{ EU-15 } \\
\hline const & -0.248813 & 0.198579 & -1.2530 & 0.22399 & & \multirow[t]{2}{*}{0.62} \\
\hline$\Delta Y$ & 0.496218 & 0.0847502 & 5.8551 & $<0.00001$ & **** & \\
\hline \multicolumn{7}{|c|}{ Japan } \\
\hline const & -0.342783 & 0.184164 & -1.8613 & 0.07676 & $*$ & \multirow[t]{2}{*}{0.28} \\
\hline$\Delta Y$ & 0.259552 & 0.0771536 & 3.3641 & 0.00294 & $* * *$ & \\
\hline \multicolumn{7}{|c|}{ China } \\
\hline const & 1.44298 & 0.207523 & 6.9534 & $<0.00001$ & *** & \multirow[t]{2}{*}{0.31} \\
\hline$\Delta Y$ & -0.0691245 & 0.0222397 & -3.1082 & 0.00532 & *** & \\
\hline \multicolumn{7}{|c|}{ India } \\
\hline const & 2.07123 & 0.31647 & 6.5448 & $<0.00001$ & $* * *$ & \multirow[t]{2}{*}{0.01} \\
\hline$\Delta Y$ & -0.00369669 & 0.0473885 & -0.0780 & 0.93856 & & \\
\hline
\end{tabular}

Source: own calculations.

According to the data presented in the table above, in the case of the most economically developed countries included in the Global Triad there were positive and statistically significant coefficients of the employment elasticity, but the highest value of this indicator was found in the United States. Hence, it follows that in these three economies (USA, EU-15, Japan) economic growth has contributed to a significant increase in employment. However, the negative employment elasticity coefficients were found in the case of China and India, while in the latter case the employment elasticity coefficient was statistically insignificant. Thus, among the analyzed countries, only in the case of China and India the existence of a phenomenon of jobless economic growth was confirmed.

In many empirical studies on the impact of economic growth on employment the authors assumed a linear function of changes in economic growth, due to the ease of estimates and clarity in the interpretation. 
However, empirical analysis confirmed that economic growth is not a linear function (Barczyk, 2006). Thus, in this case there is a need to distinguish the cyclical changes from trend of development. For this purpose, in this paper Hodrick-Prescott filter was used, which assumes that the cyclical component of the variable is the difference between the current value and the value of the trend, which is a weighted average of past, present and future observations. Then the employment elasticity is defined as the percentage change in the size of the deviation from the trend of employment in relation to one percent change in deviation from trend growth. The above relationship can be represented in accordance with the following equation:

$$
h p_{-} \Delta L_{t}=\alpha+\varphi \cdot h p_{-} \Delta Y_{\mathrm{t}}+\mu_{t}
$$

where:

$\mathrm{hp} \_\Delta \mathrm{L}$ - cyclical changes in employment;

hp_ $\Delta \mathrm{Y}$ - cyclical changes in economic growth;

$\varphi-$ the employment elasticity coefficient.

As in the previous model, also in this case, all the time series had an annual frequency and covered the period from 1990 to 2012 (Figure 4).

Figure 4. Cyclical changes in economic growth and employment in the analyzed countries in the period 1990-2012

USA

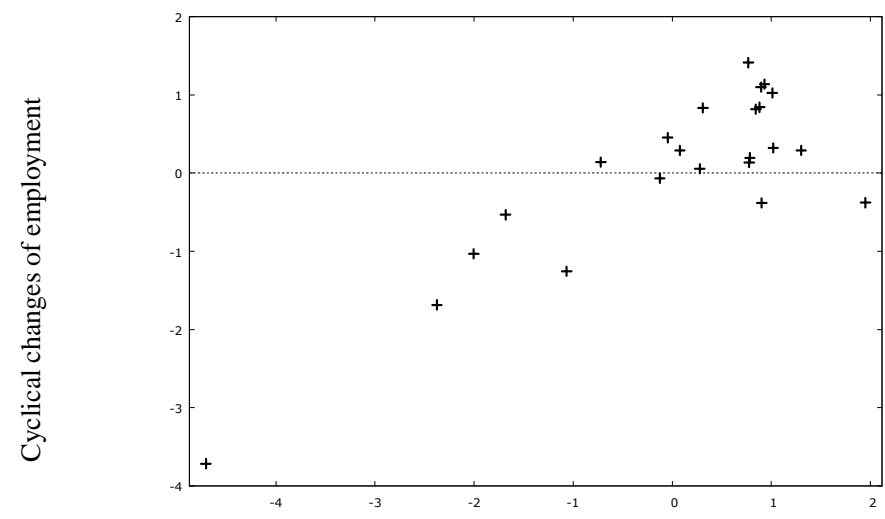

Cyclical changes of economic growth 
Figure 4 Continued

EU-15
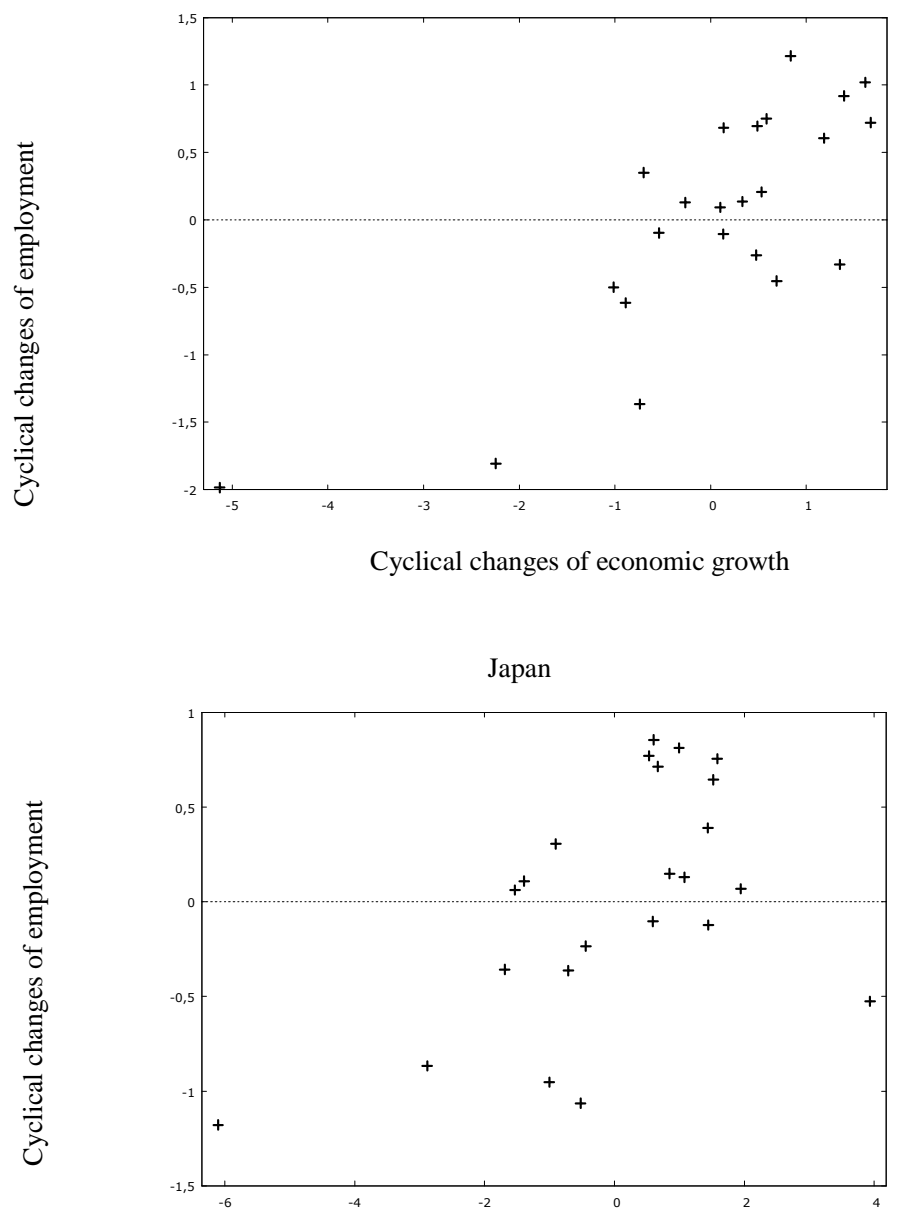
Figure 4 Continued

Cyclical changes of economic growth

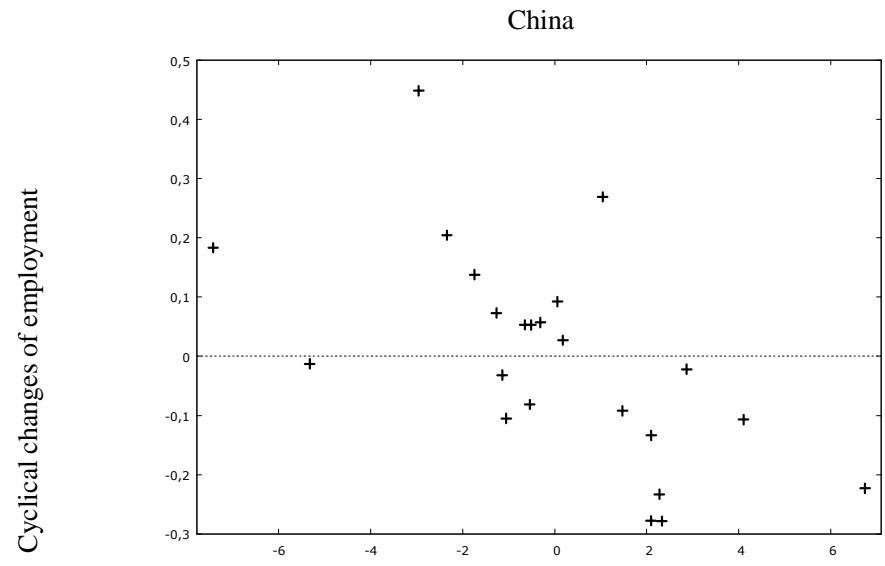

India

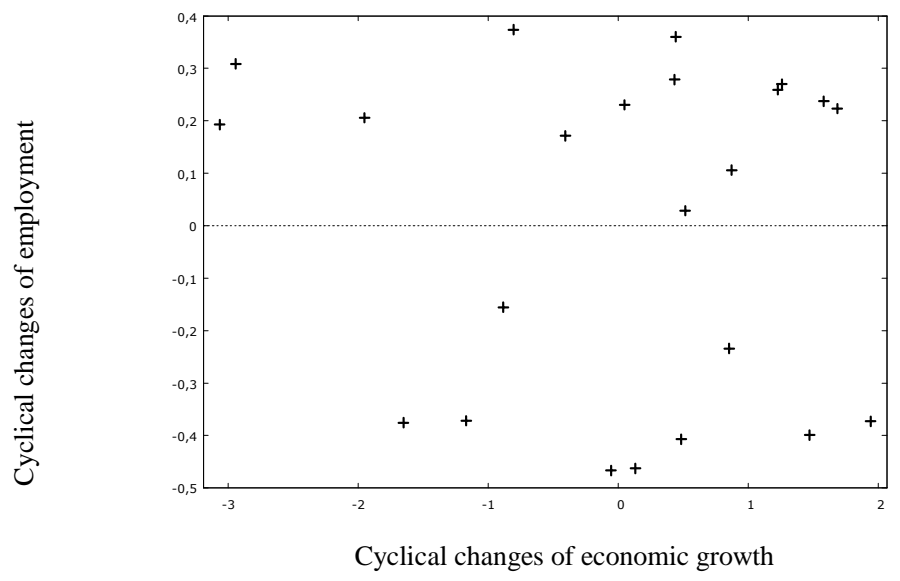

Source: own study based on The Conference Board Total Economy Database (2012).

According to the Figure 4, in the case of the U.S., EU-15 and Japan equilibrium occurred in situation of relatively high cyclical changes in economic growth and employment, which means the rejection of the jobless economic growth hypothesis in these countries. On the other hand, in the case of China and India, equilibrium took place both in situation of relative- 
ly high and low cyclical changes in economic growth, and high and low cyclical changes in employment, which does not give a clear answer regarding the presence or absence of the jobless economic growth hypothesis.

However, on the basis of data from the above figure calculated correlation coefficients between the cyclical movements of economic growth and cyclical changes in employment in the surveyed economies pointed to the absence of the jobless economic growth hypothesis in the U.S., the EU-15 and Japan, and the presence of this hypothesis in China and India.

Table 4. The correlation coefficients between the cyclical changes in economic growth and employment in the analyzed countries in the period 1990-2012

\begin{tabular}{|l|c|c|c|c|c|}
\hline Countries & USA & EU-15 & Japan & China & India \\
\hline The correlation coefficient & 0.84 & 0.80 & 0.53 & -0.61 & -0.10 \\
\hline
\end{tabular}

Source: own calculations.

Similar conclusions can be drawn after estimating equation (7) with the Ordinary Least Squares method, but the values of the estimated coefficients of impact of cyclical changes in economic growth on the cyclical changes in employment were relatively higher than the corresponding coefficients calculated for the total changes of economic growth and employment.

According to the data presented in the table 5, it can be seen that for the three most developed economies belonging to the Global Triad, elasticity coefficients of cyclical changes in employment to cyclical changes in economic growth were positive and statistically significant, and the highest value of this indicator was found in the United States. Thus, the results of the estimation show that in the case of the U.S., EU-15 and Japan economic growth led to significant changes in employment. Namely, economic growth contributed to employment growth in these countries and the economic slowdown led to a decline in employment. On the other hand, negative values of elasticity coefficients of cyclical changes in employment to cyclical changes in economic growth were revealed in China and India, but the elasticity coefficient of cyclical changes in employment was not statistically significant in India. Hence, it follows that only in the case of China and India we could talk about the occurrence of the jobless economic growth phenomenon. This phenomenon could be a consequence of the occurrence of a strong technological shock reducing in a sustainable way a labor intensity of economic growth in these countries, which is quite a common situation, in particular in developing countries and transition economies. 
Table 5. The estimation equation (7) using OLS, observations used 1990-2012 (N =23), dependent variable: $h p \_\Delta L$

\begin{tabular}{|c|c|c|c|c|c|c|}
\hline & Coefficient & Stand. error & t-ratio & $p$-value & Significance & $\mathbf{R}^{2}$ \\
\hline \multicolumn{7}{|c|}{ USA } \\
\hline const & 0 & 0.130171 & -0.0000 & 1.00000 & & \multirow[t]{2}{*}{0.71} \\
\hline$h p \_\Delta Y$ & 0.631383 & 0.0884622 & 7.1373 & $<0.00001$ & **** & \\
\hline \multicolumn{7}{|c|}{ EU-15 } \\
\hline const & 0 & 0.10979 & 0.0000 & 1.00000 & & \multirow[t]{2}{*}{0.64} \\
\hline$h p \_\Delta Y$ & 0.46402 & 0.0763244 & 6.0796 & $<0.00001$ & $* * *$ & \\
\hline \multicolumn{7}{|c|}{ Japan } \\
\hline const & 0 & 0.112679 & -0.0000 & 1.00000 & & \multirow[t]{2}{*}{0.28} \\
\hline$h p \_\Delta Y$ & 0.166775 & 0.0575848 & 2.8962 & 0.00864 & $* * *$ & \\
\hline \multicolumn{7}{|c|}{ China } \\
\hline const & 0 & 0.0303896 & 0.0000 & 1.00000 & & \multirow[t]{2}{*}{0.37} \\
\hline$h p \_\Delta Y$ & -0.0362085 & 0.010326 & -3.5066 & 0.00210 & **** & \\
\hline \multicolumn{7}{|c|}{ India } \\
\hline const & 0 & 0.0658444 & 0.0000 & 1.00000 & & \multirow[t]{2}{*}{0.01} \\
\hline$h p \_\Delta Y$ & -0.0229099 & 0.0474503 & -0.4828 & 0.63422 & & \\
\hline
\end{tabular}

Source: own calculations.

\section{Conclusions}

The results of the research provide an overview of the theoretical and empirical analysis of the relationship between economic growth, employment and productivity. While the results of the research do not constitute advice and recommendations to the economic policymakers, the results of the analysis can be a contribution to the further research concerning the impact of economic growth on changes in employment in countries with different levels of economic development. In addition, the results of the study can be a starting point for further studies aimed to construction of a strategy for growth and economic development in Poland, while maintaining an optimum balance between the promotion of employment and labor productivity growth.

In the light of theoretical analysis and empirical studies, it may indicate the presence of a variety of factors that determine the correlation between economic growth and employment. According to Schmid (2008) the form of economic growth (extensive or intensive) is an important determinant of the relation between employment growth and economic growth. Thus, economic growth may be a consequence of growth of the production factors, 
i.e., labor force and capital (extensive growth) or productivity growth of production factors (intensive growth), or alternatively, may be a consequence of a combination of these two options mentioned above. Moreover, the scope of the impact of economic growth on employment varies depending on many other factors such as the level of economic development, the level of technical progress, institutional changes associated with the labor market, wage policy, etc.

In addition, some economists emphasize the need to distinguish between the impact of economic growth on labor demand and labor supply. They claim that the elasticity of employment is determined by the structure of technology and preferences of employers, and therefore it is not appropriate to identify the labor-saving technology with a reduction in employment (Choi, 2007).

\section{References}

Altman M. (2003), Jobless or Job Creating Growth? Some preliminary thoughts, Paper presented at the TIPS/ DPRU Annual Forum, 8 - 10 September.

Ark B., Frankema E., Duteweerd H. (2004), Productivity and Employment Growth: An Empirical Review of Long and Medium Run Evidence, Groningen Growth and Development Centre, May.

Barczyk R. (2006), Morfologia cykli koniunkturalnych w gospodarkach rynkowych $i$ w systemach okresu transformacji [in:] Barczyk R., Kąsek L., Lubiński M., Marczewski K., Nowe oblicza cyklu koniunkturalnego, PWE, Warszawa.

Choi Ch. (2007), The Employment Effect of Economic Growth: Identifying Determinants of Employment Elasticity, "FTA, Regional Integration, and Development", Busan, Korea, December 18-19.

Islam R. (2010), The Challenge of Jobless Growth in Developing Countries: An analysis with Cross-country Data, Bangladesh Institute of Development Studies, Occasional Paper Series, No 1.

Kapsos S. (2005), The employment intensity of growth: Trends and macroeconomic determinants, International Labour Office, Employment Strategy Papers, No 12.

Khemraj T., Madrick J., Semmler W. (2006), Okun's Law and Jobless Growth, Schwartz Center for Economic Policy Analysis, No 3.

Marczewski K. (2006), Charakterystyka krótkookresowych zmian cyklicznych w Polsce po 1995 r. [in:] Barczyk R., Kąsek L., Lubiński M., Marczewski K., Nowe oblicza cyklu koniunkturalnego, PWE, Warszawa.

Onaran Ö. (2008), Jobless growth in the Central and Eastern European Countries, Political Economy Research Institute, Working Paper Series, No 165. 
Saget C. (2000), Can the level of employment be explained by GDP growth in Transition Countries (theory versus the quality of data), International Labour Office, Development Policy Group, Geneva.

The Conference Board Total Economy Database (2012), New York, http://www.conference-board.org/data/economydatabase.

Appendix 1. Changes in economic growth and employment in selected countries in the period $1990-2012$
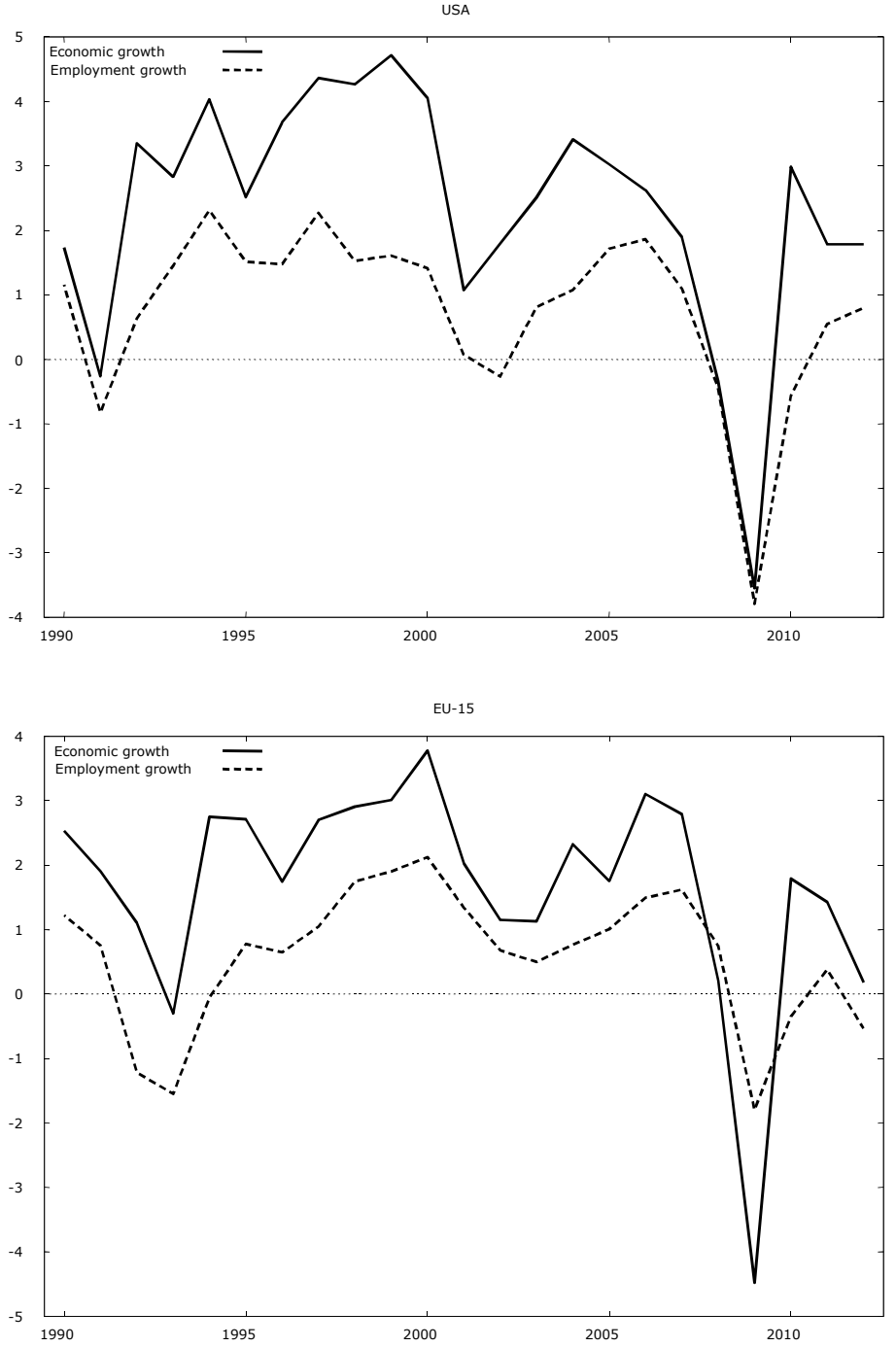

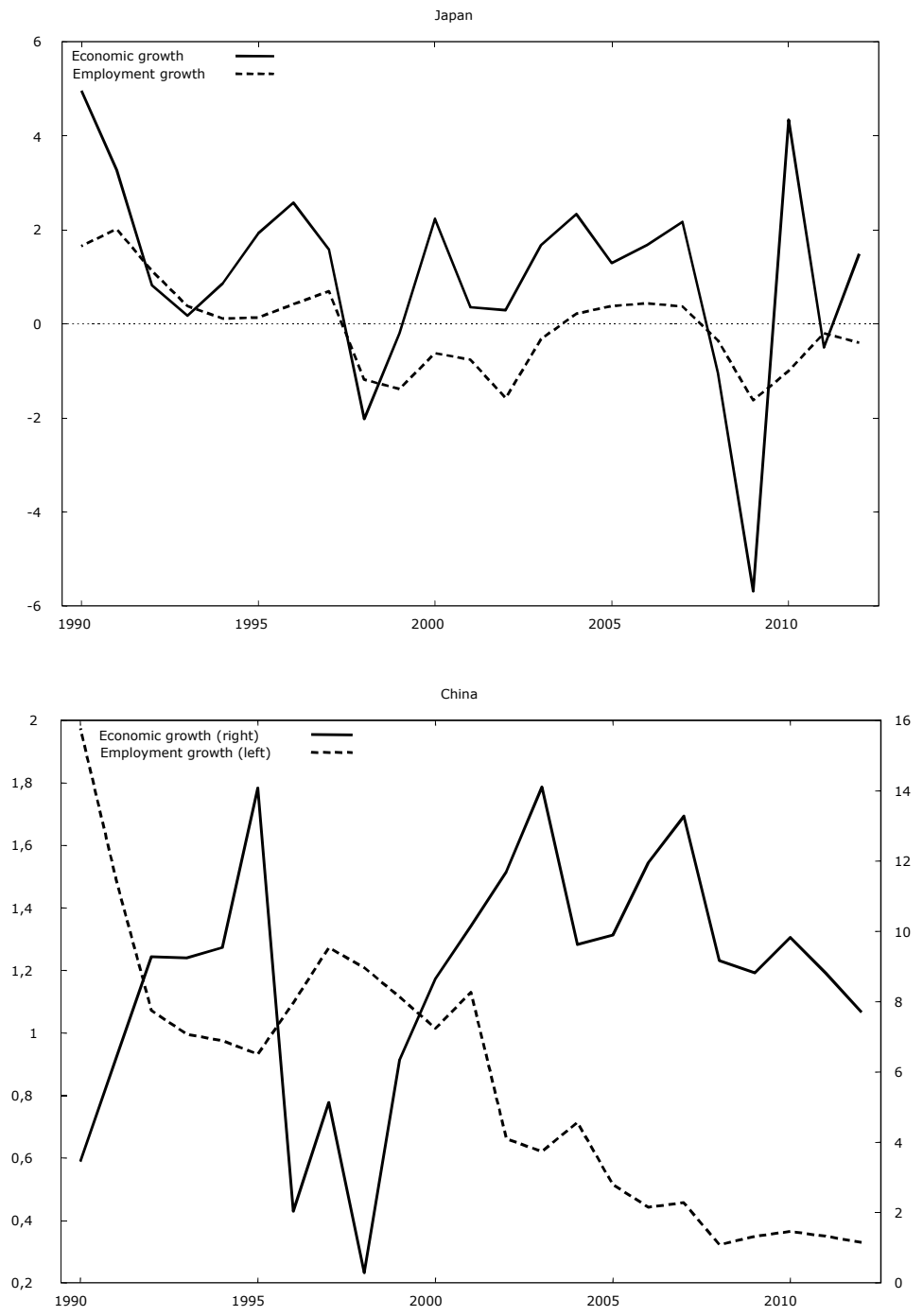


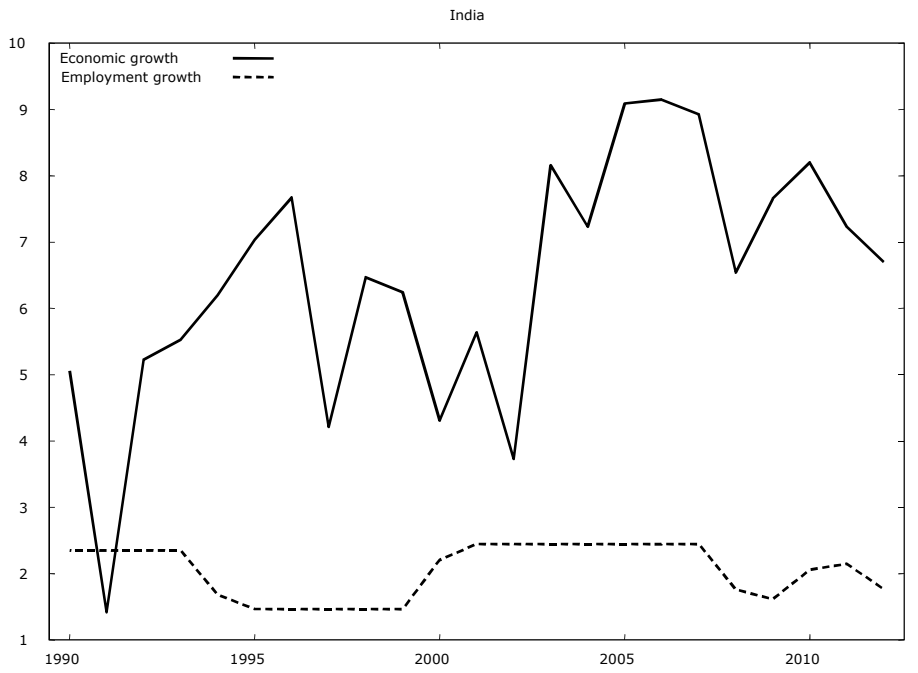

Source: own study based on The Conference Board Total Economy Database (2012). 